\title{
AN EMPIRICAL ANALYSIS ON THE RELATIONSHIP BETWEEN RENEWABLE ENERGY CONSUMPTION, HEALTH CARE EXPENDITURES AND CARBON DIOXIDE EMISSION IN THE EUROPEAN UNION COUNTRIES AND TURKEY
}

\author{
Çiğdem Börke TUNALI ${ }^{1}$
}

\author{
Naci Tolga SARUÇ²
}

\begin{abstract}
In the existing literature, although there are many studies which empirically investigate the relationship among energy consumption, economic growth and carbon dioxide emission the number of studies which analyse the causality between health care expenditures and carbon dioxide emission is very low. However, as health care expenditures can affect carbon dioxide emission, the changes in carbon dioxide emission can lead to the significant changes in health care expenditures. The aim of this study is to empirically investigate the causality relationship among renewable energy consumption, health care expenditures and carbon dioxide emission in the European Union countries and Turkey. In the empirical analysis, panel Granger causality test which is developed by Dumitrescu and Hurlin (2012) is calculated by using a dataset covering the period between 2000 and 2014 for 27 European Union countries and Turkey. According to the results of the empirical analysis, it is found that there is not a causality relationship between health care expenditures-carbon dioxide emission and health care expenditures-renewable energy. However, the results show that there is a unidirectional causality between renewable energy and carbon dioxide emission and the direction of this causality is from carbon dioxide emission to renewable energy. The existence of this relationship between carbon dioxide emission and renewable energy indicates that the level of carbon dioxide emission is taken into account in renewable energy investments and the policies that aim to increase the usage of renewable energy. Since the dataset used in the empirical analysis covers a short period of time and this may lead to the non-causality results between health care expenditures-carbon dioxide emission and health care expenditures-renewable energy it is required to do new empirical analyses by using longer datasets in order to assess the relationship between these variables more accurately in the future.
\end{abstract}

Keywords: Renewable energy consumption, health care expenditures, carbon dioxide emission, European Union countries, Turkey

JEL Code: I10, Q20, Q40, Q54

\section{Introduction}

In recent years, carbon dioxide emission, the effects of carbon dioxide emission on economic growth and climate change and the decelerating impact of the renewable energy usage on climate change are intensively debated in the economics literature and hence, there are many studies which empirically investigate the relationship between carbon dioxide emission, economic growth and renewable energy in the existing literature.

Acaravcı and Öztürk (2010) investigate the relationship between energy consumption, carbon dioxide emission and economic growth for 19 European countries over the period 1960-2005

\footnotetext{
1 Assoc. Prof., Istanbul University, cbtunali@istanbul.edu.tr (corresponding author)

2 Prof., Istanbul University, naci.saruc@istanbul.edu.tr
} 
(The dataset covers 1970-2005 for Germany and 1965-2005 for Hungary.). The authors use Autoregressive Distributed Lag (ARDL) model in their empirical analysis and come to the conclusion that there is a long-run relationship between the variables under investigation for Denmark, Germany, Greece, Iceland, Italy, Portugal and Switzerland (Acaravcı and Öztürk, 2010). Bloch et al. (2012) examine the relationship between coal consumption and output in China over the period 1977-2008 and 1965-2008 by drawing on cointegration analysis and Vector Error Correction model. According to the results of the supply-sided analysis, it is found that there is a one-way relationship from coal consumption to output (Bloch et al., 2012). However, the results of the demand-sided analysis indicate a unidirectional relationship from output to coal consumption (Bloch et al., 2012). El Hedi Arouri et al. (2012) analyse the relationship between energy consumption, economic growth and carbon dioxide emission for Middle East and North African countries by using a dataset covering the period 1981-2005. In the empirical analysis, new panel unit root tests and cointegration analysis are used and it is found that while energy consumption has a positive effect on carbon dioxide emission there is a quadratic relationship between gross domestic product and carbon dioxide emission (El Hedi Arouri et al., 2012).

Doğan and Şeker (2016) investigate the effects of renewable and unrenewable energy on carbon dioxide emission for European Union countries over the period 1980-2012. In the empirical analysis, Dynamic Ordinary Least Squares (DOLS) methodology and Panel Granger causality test which is developed by Dumitrescu and Hurlin (2012) are used (Doğan and Şeker, 2016). According to the results of the empirical analysis, the authors argue that whilst there is a two-way relationship between renewable energy consumption and carbon dioxide emission the relationship between carbon dioxide emission-unrenewable energy and carbon dioxide emission-openness is unidirectional (Doğan and Şeker, 2016). Zoundi (2017) examines the effect of renewable energy on carbon dioxide emission and the validity of the environmental Kuznets Curve in 25 African countries by using a dataset covering the period between 1980 and 2012 . According to the results of the empirical analysis, it is found that environmental Kuznets Curve hypothesis is not valid and renewable energy has a negative effect on carbon dioxide emission (Zoundi, 2017). Wang et al. (2018) analyse the relationship among urbanization, economic development, energy consumption and carbon dioxide emission for 170 countries with different income levels over the period 1980-2011. In the empirical analysis, panel cointegration, Granger causality tests, impulse response functions and variance decomposition are estimated (Wang et al., 2008). According to the results of the empirical analysis, the authors argue that there is a cointegrating relationship between the variables and among the energy consumption, economic growth and urbanization there is a two-way causality (Wang et al., 2008). Moreover, Wang et al. (2008) put forward that the relationship between energy consumption-economic growth and economic growth-urbanization is bi-directional.

To summarize, when we assess existing studies in the literature we find that although there are many studies which investigate the relationship between carbon dioxide emission, economic growth and renewable energy none of these studies takes into account a health variable in their empirical analyses. The aim of this study is to fill this gap in the existing literature by examining the causality relationship between renewable energy consumption, health care expenditures and carbon dioxide emission for the European Union countries and Turkey. Accordingly, in the second section the dataset and methodology used in the empirical analysis are explained, in the third section the results of the empirical analysis are discussed in detail. Finally, in the last section the results of the empirical analysis are summarized and a general assessment is presented. 


\section{Data and Methodology}

In this study, the dataset obtained from the World Bank World Development Indicators (World Bank, 2019) is used in order to investigate the causality relationship among renewable energy consumption, health care expenditures and carbon dioxide emission for 27 European Union countries $^{3}$ and Turkey over the period 2000-2014.

The variables used in the empirical analysis are as follows: per capita carbon dioxide emission (metric tons), renewable energy consumption as a ratio of total energy consumption (\%) and current health care expenditures as a share of GDP (gross domestic product) (\%). In the empirical analysis, all variables are used in natural logarithmic forms.

The causality relationship among renewable energy consumption, health care expenditures and carbon dioxide emission is analysed by using the methodology developed by Dumitrescu and Hurlin (2012) to test Granger causality in panel datasets.

The causality test developed by Granger (1969) can be stated by the following equation:

$X_{t}=\sum_{k=1}^{m} a_{k} X_{t-k}+\sum_{k=1}^{m} b_{k} Y_{t-k}+\varepsilon_{t}$

In this equation, $X_{t}$ and $Y_{t}$ are stationary time series and $\varepsilon_{t}$ is the error term. According to the basic assumption of Granger (1969) causality test, if past values of $Y$ are statistically significant predictors of the current values of $X$ even when past values of $X$ have been included in the model, then $Y$ has a causal effect on X (Granger, 1969; Lopez and Weber, 2017). This causality can be determined by testing the following hypothesis with an F test (Granger, 1969; Lopez and Weber, 2017):

$H_{0}: \beta_{1}=\ldots=\beta_{m}=0$

Rejecting the $\mathrm{H}_{0}$ hypothesis indicates that there is a causal relationship from $\mathrm{Y}$ to $\mathrm{X}$ (Granger, 1969; Lopez and Weber, 2017).

Dumitrescu and Hurlin (2012) developed Granger (1969) causality test in order to apply it to panel datasets. The causality test of Dumitrescu and Hurlin (2012) can be stated by the following equation:

$X_{i, t}=\alpha_{i}+\sum_{k=1}^{m} \beta_{i}^{(k)} X_{i, t-k}+\sum_{k=1}^{m} \gamma_{i}^{(k)} Y_{i, t-k}+\varepsilon_{i, t}$

In this equation, $\mathrm{X}$ and $\mathrm{Y}$ are stationary variables observed during $\mathrm{T}$ periods for $\mathrm{N}$ individuals and $\varepsilon_{i, t}$ is the error term (Dumitrescu and Hurlin, 2012). In the above equation it is assumed that coefficients are time-invariant but they are allowed to differ among individuals (Dumitrescu and Hurlin, 2012; Lopez and Weber, 2017). Moreover, it is assumed that $m$ is identical for all individuals and panel should be balanced (Dumitrescu and Hurlin, 2012; Lopez and Weber, 2017).

Similar to Granger (1969) causality test, $\mathrm{H}_{0}$ hypothesis for the causality test developed by Dumisterscu and Hurlin (2012) states that there is no causality among the individuals in the panel dataset and this hypothesis is shown as follows:

$H_{0}: \beta_{i 1}=\ldots=\beta_{i m}=0 \quad \forall i=1, \ldots, N$

This hypothesis is tested by using Wald statistic and the rejection of this hypothesis shows that there is a Granger causality (Dumitrescu and Hurlin, 2012; Lopez and Weber, 2017). It should be emphasized that this test analyses causality at the panel level and hence, it does not exclude the 
situation of non-causality between some variables in the panel (Dumitrescu and Hurlin, 2012; Lopez and Weber, 2017). Thus, the rejection of $\mathrm{H}_{0}$ indicates that there is a causality relationship only for some individuals in the panel (Dumitrescu and Hurlin, 2012; Lopez and Weber, 2017). This test is calculated in Stata 13 by using the code written by Lopez and Weber (2017).

\section{Results}

As it is stated in the previous section, determining whether the panel dataset is stationary is required in order to do Granger causality analysis. Table 1 presents whether the variables are stationary or not according to the results of the Im-Pesaran-Shin (2003) unit root test and Fisher Type Augmented Dickey-Fuller unit root test (Choi, 2001). In the Fisher Type Augmented DickeyFuller unit root test $p$ values obtained from different panel unit root tests are combined by using the methodology proposed by Choi (2001) (Stata, 2019). In both of the unit root tests $\mathrm{H}_{0}$ hypothesis states that all panels contain unit roots and hence, the rejection of $\mathrm{H}_{0}$ hypothesis indicates that panel is not stationary (Stata, 2019). According to the unit root test results (Table 1), all series contain unit root at the level, however when the first difference of the series are taken they become stationary. Thus, the first difference of the series is used in the Granger causality analysis.

Table 1. Im-Pesaran-Shin ve Augmented Dickey-Fuller Unit Root Test Results

\begin{tabular}{|l|c|c|}
\hline \multicolumn{1}{|c|}{ Variables } & $\begin{array}{c}\text { Im-Pesaran-Shin Unit Root } \\
\text { Test } \\
\text { (W-t-bar Statistic) }\end{array}$ & $\begin{array}{c}\text { Augmented Dickey-Fuller } \\
\text { Unit Root Test } \\
\text { (Inverse } \boldsymbol{\chi}^{2} \text { Statistic) }\end{array}$ \\
\hline Carbon Dio. Emission & 6.7048 & 16.5797 \\
\hline Health Care Exp. & -0.3439 & 55.3704 \\
\hline Renewable Energy & 6.5140 & 12.2692 \\
\hline$\Delta$ Carbon Dio. Emission & $-13.5058^{* * *}$ & $192.5906^{* * *}$ \\
\hline$\Delta$ Health Care Exp. & $-10.5539^{* * *}$ & $203.5428^{* * *}$ \\
\hline$\Delta$ Renewable Energy & $-10.8105^{* * *}$ & $195.3803^{* * *}$ \\
\hline
\end{tabular}

Source: Authors' estimations.

Note: $* * *$ shows $p<0.01$. All tests are estimated by using a constant term. Lag length is selected according to the Akaike Information Criterion. Stata 13 is used for the estimations.

After investigating the stationarity of the series we estimate panel Granger causality test which is developed by Dumitrescu and Hurlin (2012). The results of this test are presented in Table 2.

According to the results in Table 2, there is not a causality relationship between health care expenditures-carbon dioxide emission and health care expenditures-renewable energy. However, there is a one-way causality relationship between carbon dioxide emission and renewable energy and the direction of this relationship is from carbon dioxide emission to renewable energy. It can be stated that the reason why there is not a causality relationship between health care expenditures-carbon dioxide emission and health care expenditures-renewable energy stems from the fact that the dataset covers a short period of time (2000-2014). The existence of a one-way relationship between carbon dioxide emission and renewable energy indicates that the level of carbon dioxide emission is taken into account in renewable energy investments and the policies implemented to increase the consumption of renewable energy 
in the European Union countries and Turkey. Without doubt, together with the increase of the share of renewable energy in total energy consumption renewable energy will be influential on carbon dioxide emission in the future.

Table 2: Panel Granger Causality Test Results

\begin{tabular}{|l|c|}
\hline \multicolumn{1}{|c|}{ Hypotheses } & $\begin{array}{c}\text { Granger Causality Test Results } \\
\text { (Z-bar tilde Statistic) }\end{array}$ \\
\hline $\begin{array}{l}\text { Health care exp. does not Granger cause carbon dioxide } \\
\text { emission. }\end{array}$ & $\begin{array}{c}1.4370 \\
\text { (p-value: } 0.1507)\end{array}$ \\
\hline $\begin{array}{l}\text { Carbon dioxide emission does not Granger cause health } \\
\text { care exp. }\end{array}$ & $\begin{array}{c}0.0307 \\
\text { (p-value: } 0.9755)\end{array}$ \\
\hline $\begin{array}{l}\text { Renewable energy does not Granger cause carbon dioxide } \\
\text { emission. }\end{array}$ & $\begin{array}{c}1.4347 \\
\text { (p-value: } 0.1514)\end{array}$ \\
\hline $\begin{array}{l}\text { Carbon dioxide emission does not Granger cause } \\
\text { renewable energy. }\end{array}$ & $\begin{array}{c}2.8094 \\
\text { (p-value: } 0.0050)\end{array}$ \\
\hline Health care exp. does not Granger cause renewable energy. & $\begin{array}{c}-0.6722 \\
\text { (p-value: } 0.5014)\end{array}$ \\
\hline Renewable energy does not Granger cause health care exp. & $\begin{array}{c}0.1574 \\
\text { (p-value: } 0.8750)\end{array}$ \\
\hline
\end{tabular}

Source: Authors' estimations

Note: Panel Granger causality test is estimated in Stata 13 by using the code written by Lopez and Weber (2013). Lag length is selected according to the Akaike Information Criterion.

\section{Conclusion}

In recent years, although there are many studies which empirically investigate the relationship between energy consumption and carbon dioxide emission the number of studies which examine the causality relationship among renewable energy consumption, health care expenditures and carbon dioxide emission is very low. The aim of this study is to examine the relationship among renewable energy consumption, health care expenditures and carbon dioxide emission in the European Union countries and Turkey empirically.

In the empirical analysis, it is tried to determine the direction of causality relationship among renewable energy consumption, health care expenditures and carbon dioxide emission by applying panel Granger causality test developed by Dumitrescu and Hurlin (2012) to a dataset covering the period 2000-2014 for the European Union countries and Turkey. According to the results of the empirical analysis, it is found that while there is not a causality relationship between health care expenditures-carbon dioxide emission and health care expenditures-renewable energy there is a one-way relationship between carbon dioxide emission-renewable energy and the direction of this relationship is from carbon dioxide emission to renewable energy. The existence of a one-way relationship between carbon dioxide emission and renewable energy indicates that the level of carbon dioxide emission is taken into account in renewable energy investments and the policies implemented to increase the consumption of renewable energy in the European Union countries and Turkey. 
It can be stated that the reason why there is not a causality relationship between health care expenditures-carbon dioxide emission and health care expenditures-renewable energy stems from the fact that the dataset covers a short period of time (2000-2014). Hence, in order to reach more reliable and robust results new empirical analyses which use longer time periods should be done in the future.

\section{References}

Acaravcı, A. \& Öztürk, İ. (2010). "On the Relationship between Energy Consumption, $\mathrm{CO}_{2}$ Emissions and Economic Growth in Europe", Energy, Vol. 35 (12), pp.5412-5420.

Bloch, H., Rafiq, S. \& Salim, R. (2012). "Coal Consumption, $\mathrm{CO}_{2}$ Emission and Economic Growth in China: Empirical Evidence and Policy Responses", Energy Economics, Vol. 34 (2), pp.518-528.

Choi, I. (2001). "Unit Root Tests for Panel Data", Journal of International Money and Finance, Vol. 20 (2), pp.249-272.

Doğan, E. \& Şeker, F. (2016). "Determinants of $\mathrm{CO}_{2}$ Emissions in the European Union: The Role of Renewable and Non-Renewable Energy", Renewable Energy, Vol. 94, pp.429-439.

Dumitrescu, E. I. \& Hurlin, C. (2012). "Testing for Granger Non-Causality in Heterogeneous Panels”, Economic Modelling, Vol. 29 (4), pp.1450-1460.

El Hedi Arouri, M., Youssef, A. B., M'henni, H. \& Rault, C. (2012). “Energy Consumption, Economic Growth and $\mathrm{CO}_{2}$ Emissions in Middle East and North African Countries", Energy Policy, Vol. 45, pp.342-349.

Granger, W. J. (1969). "Investigating Causal Relations by Econometric Models and Cross-Spectral Methods", Econometrica, Vol. 37 (3), pp.424-438.

Im, K. S., Pesaran, M. H. \& Shin, Y. (2003). "Testing for Unit Roots in Heterogenous Panels", Journal of Econometrics, Vol. 115 (1), pp.53-74.

Lopez, L. \& Weber, S. (2017). "Testing for Granger Causality in Panel Data”, IRENE Working Paper, Working Paper No: 17-03, https://ideas.repec.org/p/irn/wpaper/17-03.html, (20.02.2019).

Stata (2019). xtunitroot Panel Data Unit Root Tests, https://www.stata.com/ manuals13/xtxtunitroot.pdf, (20.02.2019).

Wang, S., Li, G. \& Fang, C. (2018). “Urbanization, Economic Growth, Energy Consumption, and $\mathrm{CO}_{2}$ Emissions: Empirical Evidence from Countries with Different Income Levels", Renewable and Sustainable Energy Reviews, Vol. 81, pp.2144-2159.

World Bank (2019). World Development Indicators, https://databank.worldbank.org /data/reports.aspx?source=world-development-indicators, (20.02.2019).

Zoundi, Z. (2017). " $\mathrm{CO}_{2}$ Emissions, Renewable Energy and the Environmental Kuznets Curve, a Panel Cointegration Approach", Renewable and Sustainable Energy Reviews, Vol. 72, pp.1067-1075. 